\title{
Proceeding
}

Supplementary Issue: Spring Conferences of Sports Science. Costa Blanca Sports Science Week, 26-28 April 2018. Calpe.

Alicante, Spain

\section{Influence of the practice of Physical Activity on schoolchildren's Aggressiveness-Harassment}

\author{
JOSÉ LUIS UBAGO-JIMÉNEZ $\triangle$, PILAR PUERTAS-MOLERO, GABRIEL GONZÁLEZ-VALERO, \\ FEDERICO BÁEZ-MIRÓN \\ University of Granada, Spain
}

\begin{abstract}
Bullying is one of the main problems throughout the educational period in recent times. The objective of this study is to determine the relationship between the practice of Physical Activity and bullying amongst schoolchildren, using a questionnaire translated into Spanish and validated by expert judgment. In terms of results, there are statistically significant differences between children performing physical activity and bullying, with the main conclusion that the situations of bullying fluctuate according to age and the practice of Physical Activity. Key words: BULLYING, PHYSICAL ACTIVITY, PHYSICAL EDUCATION, FAMILY AND COMPETITION.
\end{abstract}

\section{Cite this article as:}

Ubago-Jiménez, J.L., Puertas-Molero, P., González-Valero, G., \& Báez-Mirón, F. (2018). Influence of the practice of Physical Activity on schoolchildren's Aggressiveness-Harassment. Journal of Human Sport and Exercise, 13(2proc), S484-S494. doi:https://doi.org/10.14198/hhse.2018.13.Proc2.32

\footnotetext{
Corresponding author. Department of Didactics of Musical, Plastic and Body Expression, University of Granada, Spain. http://orcid.org/0000-0002-7252-209X

E-mail: jlubago@ugr.es

Supplementary Issue: Spring Conferences of Sports Science. Costa Blanca Sports Science Week, 26-28 April 2018. Calpe. Alicante, Spain.

JOURNAL OF HUMAN SPORT \& EXERCISE ISSN 1988-5202

(c) Faculty of Education. University of Alicante

doi: $10.14198 / \mathrm{jhse} .2018 .13$. Proc2.32
}

S484 $|2018|$ Proc2 | VOLUME 13 


\section{INTRODUCTION}

The perception and display of violent behaviour is an undeniable sign of a profound personal and social disorder suffered by those who carry it out. The relevance of this violent behaviour in contexts such as schools usually creates social alarms but is however frequently unnoticed (Olweus, 1978; Espelage \& Swearer, 2003 and Smith, 2003).

It could be said that bullying or harassment within schools is one of the most disturbing matters in the educational context and also one of the most widely researched, especially of late. Young people spearhead a society that focuses its objectives on teachers, colleagues and even on parents (Moreno, Ramos, Martínez \& Musitu, 2010).

Schoolchildren's aggressive behaviour is understood as an extension of society's violence. Due to the close relationship between them, bullying could be considered a specific kind of general violence, thus becoming so important that detecting it early and intervening while in school can have great long-term benefits (Andershed, Kerr \& Stattin, 2001).

Bullying is an English term that defines aggressive, harmful and deliberate behaviour, persistent in time and exhibited most often by students. Power abuse is the main feature regarding the aggressor's behaviour, as well as the intention of intimidating and dominating, both physically and verbally by means of extortion and even cybernetic harassment, otherwise known as cyber bullying (Sharp \& Smith, 1994).

Harassment or bullying within schools is a global issue that can be found in primary and secondary schools, both public and private. General features that typify schoolchildren exhibiting this kind of violent behaviour are impulsiveness, peer domination, and little empathy, as well as having a poor prognosis regarding social and emotional development (Olweus, 1991). With regard to the victims of bullying, their main traits are scarce social abilities, negative reaction towards conflict, a predominance of crying and anxiety, vulnerability, unpopularity, and having few friends (Swearer, 2000). The person who exerts violence shows a high tendency towards psychosis, and as for victims, they have a high predisposition towards introversion and a low selfesteem (Cerezo, 2001).

Another decisive factor in this context is the family. The amount of underage children who show aggressive behaviour is generally higher in broken homes. Junger (1996) states that bullying originates from families with problems, erratic parents and from the use of harsh disciplinary methods and authority. Other influences in relation to perpetrators' behaviour have also been proved, such as lack of familiar cohesion, and lack of a paternal figure (Berdondini, 1996; Gibbs y Sinclair, 1999).

Occurrences of bullying have increased due to the higher conscience regarding the rights of children and teenagers and to the decrease in authoritarian parents and teachers. According to Clemence, Rochat, Cortolezzis, Dumont, Egloff and Kaiser (2001) behaviour in the school context is considered violent if it alters order using physical force, or if it causes suffering to people, such as harassment, which is more widely known as bullying.

Schoolchildren become victims of bullying when they suffer negative criticism and mockery, when they are completely ignored or excluded from the group of friends, when they are hit, kicked, pushed or locked up in a room, when lies or false statements are invented about them, when they are sent offensive messages, or 
when they are disparaged in front of their classmates as Olweus (1997) and Ruiz, Riuró \& Tesouro (2015) state.

When parents are emotionally immature or unstable, children will learn certain behavioural patterns equally immature or unbalanced. This learning takes place in the first few years of life, therefore being inside the family, and results in the spread of aggressiveness to other situations, thus hindering the development of social relationships (Moreno, Estévez, Murgui \& Musitu, 2009; Povedano, Hendry, Ramos \& Varela, 2011).

Certain elements which are positively related to bullying are associated with family such as the increased number of separations and divorces, the conflicts and disputes connected with them, families with a large number of members which reduces control over the children, disciplinary and hostile styles, low emotional support, scarce future planning, and chaos concerning behaviour which is normally learnt at home. In relation to paternal and maternal figures, these probably alter the bonds and support from parents and classmates and can cause instrumental learning by modelling aggressive behaviour that can later be used with parents as indicated by Musitu, Jiménez \& Povedano (2009).

During Primary Education, Physical Education must contribute to the development of different educational goals: socialization, autonomy, basic instrumental learning and the improvement of expressive, cognitive and communicative abilities and playfulness (Slingerland \& Borghouts, 2011). In other words, students' motor skills and abilities must be developed properly. In addition, in this sense, the subject of Physical Education acts as a tool in order to detect violent behaviour (Scarpa, Carraro, Gobbi \& Nart, 2012; Gómez-Figueroa \& Salazar, 2015; Ortega-Ruiz, Del Rey \& Casas, 2016).

Sport and physical activity appear not only as a game, but as a cultural phenomenon with sociological and aesthetic implications. Physical Education teachers must bear in mind the students' interests, contributing this way to eliminate or reduce harmful and violent habits that can affect the practice of sports; so that when this practice is properly conducted and set out it can help reinforce behaviour based on respect and tolerance, which can act as a treatment against violence. Some authors such as Hellison, 2003; Ruiz, Rodríguez, Martinek, Schilling, Durán \& Jiménez, 2006 or Shephard, Ordoñez \& Mora, 2015, suggest different intervention programs based on responsibility developed through the practice of physical and sporting activity in order to transmit moral values such as self-control, respect, autonomy, leadership and belonging to a group.

It must also be highlighted that the practice of sports not only brings physical improvements but also psychological benefits that are able to develop positive attitudes. Therefore, playing is essential for the development of a child's personality. Playing is known as a recreational and pleasant activity, necessary for the development of physical, emotional, intellectual, social and moral abilities. Through play, children are in contact with other people, they release tension, develop their personality, and learn from different experiences. They also assimilate respect and observance of rules, learn about helping, cooperation, integration, autonomy, express their emotions, sensations, desires, impulses, feelings and mood, which can establish emotional bonds, encourage the adoption of different social roles, and promote the making of friends, with moral, ethical and social rules being learnt (Viciana \& Conde, 2002 and Garaigordobil, 2008).

Over the years, aggressions have become something habitual, representing the most negative part of sport. Violence and aggression can be found not only in the sports field but also beyond this limit reaching grandstands and the surrounding area. On the media one can frequently find examples of aggressions in the sports field, but also among audience members. 
These violent patterns are not exclusive of professional sport, they are behavioural patterns that are repeated at levels considered to be the most educational in the practice of sport, with the study conducted by Moreno \& Cervelló (2003) serving as an example about motivation and aggression in young football players. Through this study, in a football league championship where players were aged between 11 and 13, they found that referees registered and penalised more than 300 aggressive behaviours throughout the championship. This means that virtually in all matches aggressive behaviour and misconducts were found in the playing area, on the fringes of what was allowed by the rules of sport.

\section{METHODOLOGY}

\section{Design and participants}

This research study presents a descriptive and cross-sectional design, where 240 children took part, $49.6 \%$ boys and $50.4 \%$ girls, aged between 8 and 13, studying at different Primary Schools in different areas of the city of Granada.

\section{Instruments and variables}

In the present research study the following variables were taken as a reference: age, gender, the practice of physical activity and number of hours, the practice of collective sports with or without contact, if the person is part of a sport federation or not, and with the domain of bullying divided between victims, witnesses and aggressors. The instrument used for the collection of data was a questionnaire translated into Spanish, validated by expert judgement and analysed in a discussion group, raising certain points in order to respond to the mentioned variables.

\section{Procedure}

The Department of didactics of Music, Plastic and Corporal Expression in the Faculty of Education of the University of Granada arranged the collaboration of the different schools. The school boards were informed about the nature of the research study and were requested to collaborate with their students. As well as this, a consent form was addressed to the person legally responsible for the teenagers, formally requesting their consent. Throughout the process, anonymity of the participants was guaranteed, clarifying that the experiment and its results were to be used exclusively for scientific purposes. The research study complied with Helsinki's Research Ethics Committee rules of 1975. We always had informed consent of the participants and confidentiality was also observed.

\section{Data analysis}

In order to analyse data, the statistical software program SPSS 24.0 was used, using different analysis techniques. This way, basic descriptors were established by using means and frequencies, whereas tables of contingency were used for the relational study.

\section{RESULTS}

The number of boys and girls was very similar, being $49.6 \%$ boys and $50.4 \%$ girls. It must be noted that the most common age was 11 years, with $36.7 \%(n=88)$, whereas the age with the least representation was 13 years, with $2.5 \%(n=6)$. The remaining ages, particularly 8 and 12 appeared more distributed with a percentage between $20-25 \%$.

A percentage of $72.5 \%(n=174)$ of the sample practised extracurricular physical activity as opposed to $27.5 \%$ $(n=66)$ who did not. As aforementioned, we found $27.5 \%$ of children did not practise extracurricular physical 
activity. Among the $72.5 \%$ who did, we should highlight that $64.6 \%$ practised physical activity because they liked it. Finally, we found two low percentages; $6.3 \%$ who practised sport because their friends also did and $1.7 \%$ because their parents forced them.

Among the 240 children studied we found $67.5 \%$ that were not part of a sports federation and $32.5 \%$ who were.

$44.2 \%$ of the analysed schoolchildren practise football, followed by individual sports without contact with $26.7 \%$ and finally the rest of the sports with less than $10 \%$ as shown in Table 1.

Table 1. Frequency and percentages of the different sports practised

\begin{tabular}{ccc}
\hline Sports & Frequency & Percentage \\
\hline No practice & 20 & $8.3 \%$ \\
Football & 106 & $44.2 \%$ \\
Collective without contact & 21 & $8.8 \%$ \\
Collective with contact & 23 & $9.6 \%$ \\
Individual without contact & 64 & $26.7 \%$ \\
Individual with contact & 4 & $1.7 \%$ \\
Other & 2 & $0.8 \%$ \\
Total & 240 & $100.0 \%$ \\
\hline
\end{tabular}

Additionally, as we can see in Table 4, we find $41.3 \%$ of the students practise sport around 3-4 times a week, $30 \%$ more than 4 times a week, and $28.8 \%$ who only practise sport during physical education classes.

$78.3 \%$ ( $n=188)$ have never suffered, harassed or witnessed violent actions and only $1.7 \%(n=4)$ have ever bullied. We also find 10\% (24 children) who have witnessed it, and another $10 \%$ who have been victims (Figure 1).

0,1

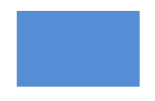

Witnesses

\section{0,017}

Aggressors
0,1

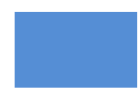

Victims

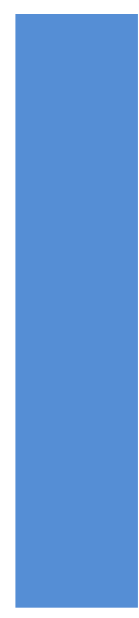

Never suffered

Figure 1. Relation of violence at school 
In the first section we do not find statistically significant differences $(p=0.725)$ between gender and bullying.

In the second section we do find statistically significant differences $(\mathrm{p}=0.001)$ between the students' age and the occurrence of bullying. These differences are established because in the aggressors we find $75 \%(n=3)$ are 12 years old and $25 \%(n=1)$ are aged 11 . In the victims group we find $41.7 \%(n=10)$ are 11 years old as opposed to $33.3 \%(n=8)$ who are 10 years old (Table 2$)$.

Table 2. Distribution of age and bullying

\begin{tabular}{|c|c|c|c|c|c|c|c|c|}
\hline \multirow{2}{*}{\multicolumn{2}{|c|}{ Bullying }} & \multicolumn{6}{|c|}{ Age } & \multirow[t]{2}{*}{ Total } \\
\hline & & 8 years & 9 years & 10 years & 11 years & 12 years & 13 years & \\
\hline \multirow{3}{*}{ Witness } & Count & 0 & 1 & 2 & 16 & 4 & 1 & 24 \\
\hline & \% Bullying & $0.0 \%$ & $4.2 \%$ & $8.3 \%$ & $66.7 \%$ & $16.7 \%$ & $4.2 \%$ & $100.0 \%$ \\
\hline & $\%$ Age & $0.0 \%$ & $10.0 \%$ & $7.1 \%$ & $18.2 \%$ & $7.0 \%$ & $16.7 \%$ & $10.0 \%$ \\
\hline \multirow{3}{*}{ Agressor } & Count & 0 & 0 & 0 & 1 & 3 & 0 & 4 \\
\hline & \% Bullying & $0.0 \%$ & $0.0 \%$ & $0.0 \%$ & $25.0 \%$ & $75.0 \%$ & $0.0 \%$ & $100.0 \%$ \\
\hline & $\%$ Age & $0.0 \%$ & $0.0 \%$ & $0.0 \%$ & $1.1 \%$ & $5.3 \%$ & $0.0 \%$ & $1.7 \%$ \\
\hline \multirow{3}{*}{ Victim } & Count & 0 & 1 & 8 & 10 & 4 & 1 & 24 \\
\hline & \% Bullying & $0.0 \%$ & $4.2 \%$ & $33.3 \%$ & $41.7 \%$ & $16.7 \%$ & $4.2 \%$ & $100.0 \%$ \\
\hline & $\%$ Age & $0.0 \%$ & $10.0 \%$ & $28.6 \%$ & $11.4 \%$ & $7.0 \%$ & $16.7 \%$ & $10.0 \%$ \\
\hline \multirow{3}{*}{ No suffering } & Count & 51 & 8 & 18 & 61 & 46 & 4 & 188 \\
\hline & \% Bullying & $27.1 \%$ & $4.3 \%$ & $9.6 \%$ & $32.4 \%$ & $24.5 \%$ & $2.1 \%$ & $100.0 \%$ \\
\hline & $\%$ Age & $100.0 \%$ & $80.0 \%$ & $64.3 \%$ & $69.3 \%$ & $80.7 \%$ & $66.7 \%$ & $78.3 \%$ \\
\hline \multirow{3}{*}{ Total } & Count & 51 & 10 & 28 & 88 & 57 & 6 & 240 \\
\hline & \% Bullying & $21.2 \%$ & $4.2 \%$ & $11.7 \%$ & $36.7 \%$ & $23.8 \%$ & $2.5 \%$ & $100.0 \%$ \\
\hline & $\%$ Age & $100.0 \%$ & $100.0 \%$ & $100.0 \%$ & $100.0 \%$ & $100.0 \%$ & $100.0 \%$ & $100.0 \%$ \\
\hline
\end{tabular}

If we observe the relation between physical activity and bullying we can highlight that no significant differences are visible ( $p=0.321)$ between those parameters. Likewise, no statistically significant differences exist $(p=0.563)$ between the reason why they practise sport and bullying. By contrast, there are statistically significant differences $(p=0.036)$ between students who are or not part of a sports federation and bullying. These differences are established because aggressors who are in a sports federation are $5.1 \%(n=4)$ while non-federated aggressors are $0 \%$. Likewise, with regards to those who have never suffered, harassed or witnessed any bullying the effect is the opposite, being $74.4 \%$ federated and $80.2 \%$ non-federated.

In the variable concerning sports practised by students and bullying, no significant differences are found $(p=0.469)$.

Finally, between the parameter of frequency (Table 3 ) of practice of physical activity and bullying, no statistically significant differences are found either $(p=0.148)$. 
Table 3. Relation between frequency of practice of sport and bullying

\begin{tabular}{|c|c|c|c|c|c|}
\hline \multirow{2}{*}{\multicolumn{2}{|c|}{ Bullying }} & \multicolumn{3}{|c|}{ Frequency of practice of sport } & \multirow{2}{*}{ Total } \\
\hline & & Only Physical Education & 3-4 times/week & +4 times/week & \\
\hline \multirow[t]{3}{*}{ Witness } & Count & 4 & 14 & 6 & 24 \\
\hline & $\%$ Bullying & $16.7 \%$ & $58.3 \%$ & $25.0 \%$ & $100 \%$ \\
\hline & $\%$ Frecuency of practice & $5.8 \%$ & $14.1 \%$ & $8.3 \%$ & $10.0 \%$ \\
\hline \multirow[t]{3}{*}{ Aggressor } & Count & 0 & 1 & 3 & 4 \\
\hline & $\%$ Bullying & $0.0 \%$ & $25.0 \%$ & $75.0 \%$ & $100 \%$ \\
\hline & $\%$ Frequency of practice & $0.0 \%$ & $1.0 \%$ & $4.2 \%$ & $1.7 \%$ \\
\hline \multirow[t]{3}{*}{ Victim } & Count & 6 & 8 & 10 & 24 \\
\hline & $\%$ Bullying & $25.0 \%$ & $33.3 \%$ & $41.7 \%$ & $100 \%$ \\
\hline & $\%$ Frequency of practice & $8.7 \%$ & $8.1 \%$ & $13.9 \%$ & $10.0 \%$ \\
\hline \multirow[t]{3}{*}{ No suffering } & Count & 59 & 76 & 53 & 188 \\
\hline & $\%$ Bullying & $31.4 \%$ & $40.4 \%$ & $28.2 \%$ & $100 \%$ \\
\hline & $\%$ Frequency of practice & $85.5 \%$ & $76.8 \%$ & $73.6 \%$ & $78.3 \%$ \\
\hline \multirow[t]{3}{*}{ Total } & Count & 69 & 99 & 72 & 240 \\
\hline & $\%$ Bullying & $28.8 \%$ & $41.2 \%$ & $30.0 \%$ & $100 \%$ \\
\hline & $\%$ Frequency of practice & $100.0 \%$ & $100.0 \%$ & $100.0 \%$ & $100 \%$ \\
\hline
\end{tabular}

\section{DISCUSSION}

This research study aims to substantiate the relation between the practice of physical activity and bullying. First, we should point out that the number of boys and girls is very similar, which contrasts with the study conducted by Cerezo (2008), where there are significant differences between genders. Among these students, the vast majority are 11 years old with only a minority being aged 13 (these 13 year olds being students held back either 1 or 2 years), with age not being an excluding factor. Other ages, mainly eight and twelve, appear more distributed.

If we focus on results concerning physical activity only, we have to highlight the great amount of students who do practise extracurricular physical activity. These results coincide with those by Casado, Alonso, Hernández \& Barrera (2009) who show in their study that $78.3 \%$ of children were active in 2003 , this being a sign of increase of sedentariness in the last years, based on what the Ministry of Health states (2006). This Ministry associates teenagers' physical inactivity with living in developed countries, therefore being a problem among young people also in Spain.

We can also see that children practise physical activity mainly because they enjoy it and not due to friends' influence or parent's insistence, encouraged mainly by the playful nature of physical activity in general and by their autonomy as stated by Chacón-Cuberos, Martínez-Martínez, Castro-Sánchez, Espejo-Garcés, Valdivia-Moral \& Zurita-Ortega, (2015).

Another major difference is related to the federation of pupils, being higher the number of non-federated as opposed to federated pupils. This can be connected to the fact that children see physical activity as recreational leisure.

Weekly practice of physical activity is also well distributed. Data shows that around three quarters of the subjects practise sport more than three hours a week. The school environment provides children and teenagers with important opportunities to be active, informally during school breaks and formally during P.E. classes (Sligerland \& Borghputs, 2011; Roman \& Taylor, 2013). It must be pointed out that physical education has an important role in the improvement of public health promoting positive attitudes and lifelong physical 
activity habits (Ntoumanis, 2001 and Fairclough, 2003). The most widely practised sport is football, thus becoming the most popular one. Individual sports without contact should also be taken into account.

Setting aside physical activity we now focus on violence within education, namely bullying. In this study we can see that eight out of ten students have never suffered bullying nor witnessed violent actions and only four children have been aggressors. Finally, we find that one out of ten students have witnessed violent actions or have been bullied, concurring with the study by Cerezo \& Méndez (2015). This data is similar to those appearing in works by Sourander, Helstela, Helenius \& Piha (2000) and Ceballos-Gurrola, MedinaRodríguez, López-Walle, \& Tristán-Rodríguez, (2014). Additionally, a large number of schoolmates know, allow and accept bullying, although they do not participate directly (Fernández \& Quevedo,1989; Ortega, 1994; Cerezo, 1994; Mcallister, 2001; Zurita, Vilches, Cachón, Padial, Martínez \& Castro, 2015). This might imply that many pupils fear being bullied, thus remaining silent and pretending not to witness any of these violent acts in order to avoid future problems (O'Connor \& Graber, 2014; Espejo, Chacón, Zurita \& Castro, 2016).

On the other hand it should also be noted that the high percentage of children who do not witness bullying does not coincide with other current articles. This could mean that participants have not answered honestly to these kinds of questions in the questionnaire.

\section{CONCLUSIONS}

As children grow, bullying also increases, that is, children become more violent.

Another key factor in relation to bullying is its relationship with the practice of sports. This study reinforces the idea that children who practise physical activity have a higher bullying index. This is due to the interaction with others and to the effect of sports competitions.

The main conclusions are that approximately $41 \%$ of schoolchildren practise physical activity regularly. The practice of football stands out with $44 \%$ and individual sports without contact with $27 \%$.

In regard to participants experiencing bullying, it stands out that $78 \%$ do not perceive bullying, whereas a tenth states having suffered or having witnessed bullying. On the contrary, only $2 \%$ have admitted having bullied in certain occasion.

Finally, relational studies have not shown differences in witnessing and harassing between both genders. Correlation between Bullying and age has shown a clear increase in children over 11 years old. It is also noticeable that a higher percentage of victims and witnesses of bullying exist when not being federated in a sport.

In conclusion, it is demonstrated how situations of bullying vary according to age and practice of physical activity. Therefore, from the area of Physical Education, an environment closer to students could be established, in order to allow working on and developing strategies for the prevention and avoidance of bullying through sport. 


\section{REFERENCES}

Andershed, M., Kerr, M. y Stattin, H. (2001). Bullying in School and Violence on the Streets: Are the Same People Involved? Journal of Scandinavian Studies in Criminology and Crime Prevention, 2(1), 31-49. https://doi.org/10.1080/140438501317205538

Arroyo, M. (2010). La actividad física y su papel en la educación. Revista de educación en Extremadura, 6, 37-49. Retrieved from: https://goo.gl/xbmRwj

Berdondini, L. (1996). Cohesion and Power in the Families of Children in Bullying/Victim Problems at School: An Italian Replication. Univ. degli Studi di Firenze. Departamento di Psicologia. Firenze.

Casado, C., Alonso, N. y Barrera, H., (2009). Actividad física en niños españoles. Factores asociados y evolución 2003-2006. Revista Pediátrica Atención Primaria, 11(42), 219-231. Retrieved from: https://goo.gl/9bCeCD

Chacón-Cuberos, R., Martínez-Martínez, A., Castro-Sánchez, M., Espejo-Garcés, T., Valdivia-Moral, P.A. y Zurita-Ortega, F. (2015). Relación entre bullying, género y actividad física: Estudio en escolares de la provincia de Granada. Trances, 7(6), 791-810. Retrieved from: https://goo.gl/CDBpYq

Ceballos-Gurrola, O., Medina-Rodríguez, R. E., López-Walle, J. M. y Tristán-Rodríguez, J. L. (2014). Percepción de la violencia durante la práctica de actividades físicas en escolares. Revista Lúdica Pedagógica, 20(2), 87-92. https://doi.org/10.17227/01214128.20ludica87.92

Cerezo, F. (1994). El cuestionario Bull. Un procedimiento para la medida de la agresividad entre escolares. Actas del IV Congreso Internacional de Evaluación Psicológica. Diputación de Pontevedra.

Cerezo, F. (2001). La violencia en las aulas. Madrid: Pirámide.

Cerezo, F. (2008). Agresores y víctimas del bullying. Desigualdades de género en la violencia entre escolares. Informació psicológica, 94, 49-59. Retrieved from: https://goo.gl/CL8aC2

Cerezo, F. y Méndez, I. (2015). Agresores en bullying y conductas antisociales. European Journal of Investigation in Health, Psychology and Education, 3(1), 5-14. Doi: 10.1989/ejihpe.v3i1.19 Retrieved from: https://goo.gl/KfdLAa

Clemence, A., Rochat, FR., Cortolezzis, C., Dumont, P., Egloff, M. y Kaiser, CL. A. (2001). Scolarité et adolescence. Les motifs de l'insécurité. Bern, Stuttgart, Wien: Haupt.

Espelage, D. L. y Swearer, S. M. (2003). Research on school bullying and victimization: What have we learned and where to we go from here? School Psychology Review, 32, 365-383. Retrieved from: https://goo.gl/hV6FHc

Espejo, T., Chacón, R., Zurita, F. y Castro, M. (2016). Victimización en edad escolar desde la perspectiva de la actividad física. Sportis, 3(2), 379-389. https://doi.org/10.17979/sportis.2016.2.3.1729

Fairclough, S. (2003a). Physical activity levels during key stage 3 physical education. British Journal of Teaching Physical Education, 34, 40-45. Retrieved from: https://goo.gl/sxC7dP

Fairclough, S. (2003b). Physical activity, perceived competence and enjoyment during secondary school physical education, European Journal of Physical Education, 8(1), 5-18. Retrieved from: https://goo.gl/bWLniM

Fernández, I. y Quevedo, G. (1989). Violence, Bullying and Counselling in the Iberian Peninsula. Bullying: and International Perspective. Londres.

Garaigordobil, M. (2008). Importancia del juego infantil en el desarrollo humano.

Gibbs, I. y Sinclair, I. (1999). Treatment and Treatment Outcomes in Children's Home. Child and Family Social Work, 4(1), (1-8). https://doi.org/10.1046/j.1365-2206.1999.00087.x 
Gómez-Figueroa, J. y Salazar, C. (2015). Detección de violencia escolar en adolescentes en la clase de educación física. Revista Iberoamericana de Psicología del Ejercicio y el Deporte, 10(1), 41-47. Retrieved from: https://goo.gl/NwdX69

Hellison, D. (2003). Teaching responsibility through physical activity. Illinois: Human Kinetics.

Junger, T. J. (1996). Youth and violence in Europe. En Studies on Crime and Crime Prevention, 5(1), pp. 31-58. Norway Scandinavia Univ. Press.

Mcallister, L. (2001). Good Kids, Bad Behavior: A Study of Bullying Among Fifth- Grade School Children. Dissertation- Abstract- International, A: The humanities and social sciencies, 61.

Ministerio de Sanidad y Consumo (2003). Sanitarios en España. Madrid (España).

Ministerio de Sanidad y Consumo (2006). Datos básicos de la salud y los servicios. Madrid (España).

Moreno, D., Estévez, E., Murgui, S. y Musitu, G. (2009). Relación entre el clima familiar y el clima escolar: El rol de la empatía, la actitud hacia la autoridad y la conducta violenta en la adolescencia. International Journal of Psychology and Psychological Therapy, 9(1), 123-136. Retrieved from: https://goo.gl//55krfP

Moreno, D., Ramos, M. J., Martínez, B. y Musitu, G. (2010). Agresión manifiesta y ajuste psicosocial en la adolescencia. Summa Psicológica UST, 7(2), 45-54. Retrieved from: https://goo.gl/zN8cVe

Moreno, J. A. y Cervelló, E. (2003). Pensamiento del alumno hacia la Educación Física: su relación con la práctica deportiva y el carácter del educador. Enseñanza, 21, 345- 362. Retrieved from: https://goo.gl/2HDLSL

Musitu, G., Jiménez, T. I. y Povedano, A. (2009). Familia y Escuela: Escenarios de Riesgo y de Protección en la Violencia Escolar. Revista Electrónica de Motivación y Emoción, 12, 32-33. Retrieved from: https://goo.gl/NBxewF

Ntoumanis, N. (2001). A self-determination approach to the understanding of motivation in physical education, British Journal of Educational Psychology, 71, 225-242. Retrieved from: https://goo.gl/h4mKx5

O'Connor, J. y Graber, K. (2014). Sixth-Grade Physical Education: An Acculturation of Bullying and Fear. Research Quarterly for Exercise and Sport, 85(3), 398-408. https://doi.org/10.1080/02701367.2014.930403

Olweus, D. (1978). Agression in the Schools: Bullies and Whipping Boys. Washington: Hemisphere.

Olweus, D. (1991). Bully/victim problems in school: Facts and intervention. European Journal of Psychology of Education 12, 495-510. Retrieved from: https://goo.gl/eYmVR6

Olweus, D. (1997). Bully/Victim Problems in School: Knowledge Base and an Effective Intervention Program. Irish Journal of Psychology, 18(2),170-190. https://doi.org/10.1080/03033910.1997.10558138

Ortega, R. (1994). Violencia interpersonal en los centros educativos de enseñanza secundaria. Un estudio sobre el maltrato e intimidación entre compañeros. Revista de Educación. MEC, 304, 253280. Retrieved from: https://goo.gl/na7UaM

Ortega-Ruiz, R., Del Rey, R. y Casas, J. A. (2016). La Convivencia Escolar: clave en la predicción del Bullying. Revista Iberoamericana de Evaluación Educativa, 6(2), 91-102. Retrieved from: https://goo.gl/117D1g

Povedano, A., Hendry, L. B., Ramos M. J. y Varela, R. (2011). Victimización escolar: clima familiar, autoestima y satisfacción con la vida desde una perspectiva de género. Psychosocial Intervention, 20, 5-12. https://doi.org/10.5093/in2011v20n1a1

Roman, C. G. y Taylor C. J. (2013). A multilevel assessment of school climate, bullying victimization, and physical activity. Journal of School Health, 83, 400-407. https://doi.org/10.1111/josh.12043

Ruiz, R., Riuró, M. y Tesouro, M. (2015). Estudio del bullying en el ciclo superior de primaria. Educación XXI, 18(1), 345-368. https://doi.org/10.5944/educxx1.18.1.12384 
Ruiz, L. M., Rodríguez, P., Martinek, T., Schilling, T., Durán, L. J. y Jiménez, P. (2006). El proyecto esfuerzo: un modelo para el desarrollo de la responsabilidad personal y social a través del deporte. Revista de Educación, 143, 933-958. Retrieved from: https://goo.gl/NopNpE

Scarpa, S., Carraro, A., Gobbi, E. y Nart, A. (2012). Peer-victimization during physical education and enjoyment of physical activity. Perceptual and motor skills, 115(1), 319-324. https://doi.org/10.2466/06.05.10.PMS.115.4.319-324

Sharp, S. y Smith, P. K. (1994). Tackling Bullying in your School. Londres: Routledge. https://doi.org/10.4324/9780203425503

Shephard, B., Ordoñez, M. y Mora, C. (2015). Estudio Descriptivo: Programa de Prevención y Disminución del Acoso Escolar - "Bullying". Fase Diagnóstica: Prevalencia. Revista Médica HJCA, 7(2), 155-161. https://doi.org/10.14410/2015.7.2.ao.30

Slingerland, M. y Borghouts, L. (2011). Direct and indirect influence of physical education-based interventions on physical activity: a review. Journal of physical activity and health, 8(6), 866-878. https://doi.org/10.1123/ipah.8.6.866

Smith, A. L. (2003). Peer relationships in physical activity contexts: A road less traveled in youth sport and exercise psychology research. Psychology of Sport and Exercise, 4, 25-39. https://doi.org/10.1016/S1469-0292(02)00015-8

Sourander, A., Helstela, L., Helenius, H. y Piha, J. (2000). Persistence of Bullying from Childhood to Adolescence. A Longitudinal 8-Year Follow up Study. Child Abuse and Neglect, 24, 873-881. https://doi.org/10.1016/S0145-2134(00)00146-0

Swearer, S. M. (2000). Bullying and Victimization Description, Assessment and Guidelines for Intervention. Lincoln: University of Nebraska.

Viciana, V. y Conde, J.L. (2002). El juego en el currículo de Educación Infantil. En J.A. Moreno-Murcia (coord.), Aprendizaje a través del juego (pp. 67-97). Málaga: Aljibe.

Zurita, F., Castro, M., González, J., Rodríguez, S. y Pérez, A. (2016). Autoconcepto, Actividad física y Familia: Análisis de un modelo de ecuaciones estructurales. Revista de psicología del deporte, 25(1), 97-104. Retrieved from: https://goo.gl/gRVmBw

Zurita, F., Vilches, J. M., Cachón, J., Padial, R., Martínez, A. y Castro, M. (2015). Violencia escolar en adolescentes: un análisis en función de la actividad física y lugar de residencia habitual. Universitas Psychologica, 14(2), 743-754. https://doi.org/10.11144/Javeriana.upsy14-2.veaa

\section{(9) $(\mathcal{\Theta \Theta}$}

This title is licensed under a Creative Commons Attribution-NonCommercial-NoDerivs 4.0 Unported License. 